\title{
Meningkatkan Kecerdasan Emosional Siswa Melalui Kebiasaan Membaca Al-Quran
}

\author{
Ainun Jariah \\ Universitas Islam Negeri (UIN) Antasari Banjarmasin
}

\begin{abstract}
The purpose of this research is to find out the level and the correlation between the habit of reading the Qur'an to the emotional quotient of student class VIII MTs Al-Hamid Banjarmasin. This research used a quantitative approach. The data collection device uses the Likert scale, scale aspect of the habit of reading Qur'an 38 items, and emotional quotient scale 37 items that have been tested for validity and reliability. The sampling technique used was nonprobility sampling, with a total of 89 peoples - the data analysis using SPSS software for Windows 21.0. Quantitative data shows the habit of reading Qur'an in the medium category (61,79 percent) and emotional quotient in the medium type $(66,29$ percent). A correlation analysis results use a Pearson product moment technique in the can calculated $r$ value is 0,460 with $p$-value 0,000 while the $r$ table is at the 5 percent significance level with $N=89$ of 0,213 show off that the habit of reading Qur'an affected the level of emotional quotient. As for the magnitude of the contribution of the practice of reading the Qur'an variable to the emotional quotient of MTs AlHamid Banjarmasin in the amount of (rxy2 x 100) or 21,16 percent.
\end{abstract}

Keywords : Emotional Quetient; Reading the Qur'an; The Habit.

\begin{abstract}
Abstrak
Tujuan penelitian ini untuk mengetahui tingkatan dan pengaruh kebiasaan membaca AlQur'an terhadap kecerdasan emosional siswa kelas VIII MTs Al-Hamid Banjarmasin. Penelitian ini menggunakan pendekatan kuantitatif. Alat pengumpulan data menggunakan skala Likert, skalaaspek kebiasaan membaca Al-Qur'an 38 aitem dan skala kecerdasan emosional 37 aitem ini sudah di uji kevalidannya dan kereliabilitasannya, Teknik pengambilan sampel menggunakan non probility sampling, jumlah subjek sebanyak 89 siswa. Analisis data menggunakan uji korelasi dengan bantuan software SPSS for windows 21.0. Hasil data kuantitaif menunjukkan kebiasaan membaca Al-Quran kategori sedang (61,79 persen) dan kecerdasan emosional kategori sedang (66,29 persen). Hasil analisis uji korelasi menggunakan teknik Pearson Product Moment di dapat nilai $\mathrm{r}$ hitung sebesar 0,460 dengan $p$ value 0,000 sementara nilai $r$ tabel pada taraf signifikansi 5 persen dengan $N=89$ sebesar 0,213 menunjukkan bahwa tingkat kebiasaan membaca Al-Qur'an mempengaruhi tingkat kecerdasan emosional.Adapun besarnya sumbangan variabel kebiasaan membaca Al-Qur'an terhadap kecerdasan emosional siswa MTs Al-Hamid Banjarmasin sebesar (rxy2 x 100) atau 21,16 persen.
\end{abstract}

Kata kunci: Kebiasaan; Membaca Al-Quran; Kecerdasan Emosional. 
Al-Qur'an merupakan pedoman dasar yang dijadikan pegangan hidup umat Islam. Namun disisi lain Al-Qur'an memiliki banyak keistimewaan apabila seseorang membaca sekalipun belum mengetahui makna yang ada di dalam Al-Qur'an dalam segi fisik maupun psikologis. Membaca Al-Qur'an terbukti dapat mengurangi ketegangan syaraf sehingga dapat membuat seseorang menjadi lebih tenang (Mar'ati \& Chaer, 2017).

Membaca Al-Qur'an sangat dianjurkan kepada umat Muslim. Perintah membaca AlQur'an sendiri diabadikan dalam QS. Al-Alaq, ayat 1-5.

"Bacalah dengan (menyebut) nama Tuhanmu yang Menciptakan. Dia telah menciptakan manusia dari segumpal darah.Bacalah, dan Tuhanmulah yang Maha pemurah, yang mengajar (manusia) dengan perantaran kalam.Dia mengajar kepada manusia apa yang tidak diketahuinya."

Menurut Quraish Shihab, kata 'iqra' disini memiliki arti menyampaikan, menelaah, membaca, mendalami, meneliti, mengetahui. Maknanya juga berarti mengeja atau melafalkan apa yang tertulis untuk mengetahui makna yang terkandung di dalamnya. Pesan yang disampaikan oleh ayat ini adalah perintah membaca. Kata 'membaca' dalam surah ini melambangkan segala apa yang dilakukan manusia baik dari segi aktif maupun pasif. Kemudian dalam ayat selanjutnya mempunyai tujuan agar manusia memiliki kemampuan untuk menerima informasi. Secara umum menyampaikan manusia agar tidak buta huruf yang berarti juga akan buta informasi. Terus berusaha memperoleh pelajaran dari setiap informasi untuk terus belajar (Mustolehudin, 2011).

Membaca Al-Qur'an memiliki banyak manfaat terutama dalam aspek psikologis, salah satunya adalah seperti yang ada pada penelitian Erita dari fakultas kedokteran dan ilmu kesehatan. Pada penelitian tersebut didapatkan hasil bahwa membaca Al-Qur'an dengan metode tahsin dapat mengurangi tingkat depresi dan bahkan mampu menghilangkan depresi di Panti Soaial Tresna Werdha Unit Abiyoso Pakem Yogyakarta. Kemudian peneliti juga menerangkan hal tersebut dikarenakan membaca dan pemaknaan Al-Qur'an dapat mengurangi tingkat kecemasan sesuai dengan apa diterangkan oleh DR. Ahmad al-Qhadi yang mendapatkan bukti bahwa Al-Qur'an dapat mereduksi ketegangan-ketegangan syaraf sehingga akan membuat seseorang dapat lebih tenang (Mar'ati \& Toriqul Chaer, 2016).

Hal tersebut membuktikan bahwa Al-Qur'an dapat menjadi penyembuh sebagaimana firman Allah pada QS. Al-Israa' : 82: 


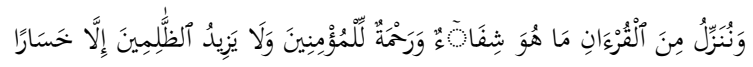

"Dan kami turunkan dari Al-Qur'an suatu yang menjadi penawar dan rahmat bagi orangorang yang beriman dan Al-Qur'an itu tidaklah menambah kepada orang-orang yang zalim selain kerugian."

Surah QS. Al-Israa' ayat 82 ini menerangkan bahwa Al-Qur'an dapat menjadi penawar serta rahmat bagi orang-orang beriman, akan tetapi tidak bagi orang-orang yang zalim selain kerugian. Sehingga makna penawar disini tidak di artikan untuk semua orang dan hanya di khususkan kepada orang-orang yang beriman.

MTs Al-Hamid Banjarmasin merupakan salah satu sekolah yang menjadikan pembacaan Al-Qur'an sebagai yang harus dilakukan pada waktu-waktu tertentu. Hal tersebut dilakukan mengingat banyaknya manfaat yang dapat diambil dari Al-Qur'an sebagai fungsinya untuk pedoman umat Islam terutama untuk sekolah yang berbasis keislaman. Para siswa dibiasakan membaca Al-Qur'an sebelum memulai pelajaran, sebelum shalat dzuhur dan sebelum pulang sekolah beserta bimbingan langsung dari para pengajar. Hal tersebut berdampak positif bagi para siswa sebagaimana yang disampaikan oleh wakil kepala sekolah selaku bidang kesiswaan menerangkan bahwa membiasakan siswa dengan membaca dan terus mempelajari AlQur'anmenghasilkan perubahan perilaku positif menjadi pribadi yang lebih sopan terhadap para guru dan lebih menghargai teman. Selain itu juga lebih baik dalam menjaga jarak atau pergaulan antar lawan jenis.Sudah banyak beberapa sekolah juga menerapkan pembecaan AlQur'an sebelum memulai pembelajaran. MTs Al-Hamid memiliki keunggulan tersendiri selain membiasakan program pembacaan Al-Qur'an disisi lain MTs Al-Hamid juga memberikan unggulan berupa program tahfidz untuk semua siswa. Setelah pembacaan Al-Qur'an di pagi hari, para siswa akan diberikan waktu untuk menyetor hafalan atau untuk memperbaiki bacaan (tahsin) Al-Qur'an yang akan dibimbing bersama ustadz dan ustadzah di masing-masing kelas (Ridwan, 2018).

Semakin berkembangnya zaman baik dalam segi ilmu maupun teknologi, mengakibatkan hampir semua hal dapat dikerjakan secara praktis. Akan tetapi, perkembangan yang terkesan positif tidak lepas dari efek negatif. Karena semua hal dapat dilakukan dengan mudah, banyak oknum-oknum menyalahgunakan perkembangan. Salah satu efek negatif adalah pergaulan remaja yang keluar dari norma agama maupun negara seperti, pergaulan bebas, penggunaan 
obat-obatan terlarang, maraknya pornografi, rusaknya moral dan pengendalian emosional terhadap diri. Salah satu kenakalan tersebut disebabkan remaja memasuki fase labil yaitu fase peralihan antara fase anak-anak menuju fase dewasa. Sehingga tak jarang pada fase ini remaja akan mengalami perubahan-perubahan dari segi fisik seperti anggota tubuh dan psikologis seperti segi emosional. Pada fase transisi ini remaja memasuki fase pencarian jati diri yang menjadi kunci dari beberapa fase yang akan membentuk kepribadian seseorang untuk menuju dewasa (Sarwono, 2012).

Hal tersebut dapat teratasi jika seorang remaja memiliki pengendalian diri yang baik sehingga ia mampu membedakan baik-buruk untuk dirinya. Pengendalian diri yang baik merupakan salah satu aspek dari kecerdasan emosional. Faktor-faktor dalam membentuk kecerdasan emosional adalah pengalaman, usia, jenis kelamin, dan lingkungan (Jati \& Yoenanto, 2013). Lingkungan merupakan salah satu faktor penting untuk membentuk kecerdasan emosional seseorang hal itulah yang menuntut orang tua untuk dapat memilihkan lingkungan yang baik untuk anak. Mengingat pada fase ini anak menghabiskan waktu di sekolah salah satu cara dapat berupa memilihkan anak sekolah yang berbasis agama. Hal tersebut dikarenakan anak tidak hanya di ajarkan pelajaran umum tetapi juga tentang pelajaran agama yang menuntun seperti akidah dan akhlak untuk menuntun dia dalam berperilaku sehingga tidak mengutamakan kecerdasan intelektual saja tapi juga kecerdasan lainnya termasuk kecerdasan emosional.

Menurut Daniel Goleman, kecerdasan emosional adalah kemampuan individu dalam mengenali perasaan, meraih dan membangkitkan perasaan untuk membantu pikiran, memaknaipikiran dan maknanya, mampu memamahi emosi dirinya maupun orang lain, dan mengendalikan perasaan secara mendalam sehingga dapat membantu perkembangan emosi dan intelektualnya. Daniel Goleman kemudian menerangkan beberapa aspek dalam kecerdasan emosional yaitu; Pertama, memiliki kesadaran mengenai emosi sendiri maupun orang lain berupa penilaian yang akurat terhadap dirinya dan percaya diri terhadap kemampuannya. Kedua, pengelolaan diri yang baik dalam mengendalikan dorongan-dorongan dari dalam diri. Mampu menyesuaikan diri dengan keadaan apapun atau terhadap tuntutan apapun tanpa kehilangan fokus ataupun energi yang berlebihan. Ketiga, memiliki kesadaran sosial yang baik, 
mampu memahami situasi, memiliki rasa empati terhadap orang lain ataupun lingkungan dan mampu mendengarkan atau membaca emosi orang lain (Goleman, 2007).

Permasalahan yang sering terjadi biasanya dilatarbelakangi permasalahan diri sendiri atau karena masalah kepada orang lain yang kemudian melakukan tindakan yang salah (Susanti, 2015). Hal ini merajuk kepada kurangnya kemampuan dalam pengendalian diri yang baik terhadap lingkungan atau situasi yang termasuk dalam kecerdasan emosional. Sehingga apabila seseorang memiliki kecerdasan emosional yang baik ia dapat mengontrol diri untuk tidak melakukan segala bentuk penyimpangan-penyimpangan yang bertentangan dengan norma-norma yang ada. Sesuai dengan pendapat Gottfredson dan Hirschi yang menerangkan bahwa seseorang yang memiliki pengendalian diri rendah, memiliki karakteristik stabil untuk melakukan tindakan-tindakan pidana atau penyimpangan sosial (Titisari, 2018). Penelitian ini bertujuan untuk membuktikan adanya pengaruh kebiasaan membaca Al-Qur'an terhadap kecerdasan emosional siswa kelas VIII MTs Al-Hamid Banjarmasin.

\section{Metode}

Penelitian ini merupakan penelitian kuantitatif korelasional. Penelitian ini menggunakan variabel bebas kebiasaan membaca Al-Qur'an dan variabel terikat kecerdasan emosional. Penelitian dilakukan di MTs Al-Hamid Banjarmasin dengan jumlah subjek sebanyak 89 siswa.Teknik pengambilan sampel menggunakan non probility sampling.Adapun skala yang digunakan untuk riset ialah Skala Aspek Kebiasaan Membaca Al-Qur'an (Syah, 2012) dan Skala Kecerdasan Emosional (Goleman, 2016).

\section{Skala Aspek Kebiasaan Membaca Al-Qur'an dan Kecerdasan Emosional}

Skala aspek kebiasaan membaca Al-Qur'an terdiri dari 38 aitem berdasarkan 4 indikator menurut Burghardt (Syah, 2012) yaitu aspek continuitas, konsistensi, perencanaan dan kesungguhan. Sedangkan skala gejala kecerdasan emosional terdiri dari 37 aitem yang memiliki 3 aspek (Goleman, 2016) yaitu kesadaran diri, pengelolaan diri dan kesadaran sosial. 


\section{Hasil}

Teknik analisis menggunakan analisis product moment dibantu dengan software Statictical Packages for Social Science (SPSS) 21.0 for Windows.

\section{Tabel 1}

Statistik deskriptif

\begin{tabular}{cccccc}
\hline & $\mathrm{N}$ & Minimum & Maximum & Mean & Std. Deviation \\
\hline $\begin{array}{c}\text { Kebiasaan } \\
\text { Membaca Al- } \\
\text { Qur'an }\end{array}$ & 89 & 102 & 150 & 125,58 & 10,473 \\
$\begin{array}{c}\text { Kecerdasan } \\
\text { Emosional }\end{array}$ & 89 & 87 & 127 & 108,16 & 7,852 \\
\hline
\end{tabular}

Tabel 2

Uji Analisis Data Kebiasaan Membaca Al-Qur'an

\begin{tabular}{cccc}
\hline & & & \\
\multirow{3}{*}{ Valid } & Frekuensi & Persentase \\
\cline { 3 - 4 } & Tinggi & 17 & 19,10 \\
& Sedang & 55 & 61,79 \\
& Rendah & 17 & 19,10 \\
& Total & 89 & 99,99 \\
\hline
\end{tabular}

Berdasarkan nilai dari mean pada angket aspek kebiasaan membaca Al-Qur'an adalah 125,58 dan standar deviasi adalah 10,473. Kemudian dari hasil tersebut dapat ditentukan subjek yang berada di kategori tinggi, sedang maupun rendah dengan menggunakan pengkategorian intensitas variabel. Diketahui bahwa tingkat kebiasaan membaca Al-Qur'an dengan kategori tinggi sebanyak 17 orang atau sebesar 19,10 persen, kategori sedang sebanyak 55 orang atau sebesar 61,79 persen, dan yang berada dalam kategori rendah sebanyak 17 orang atau 19,10 persen 


\section{Tabel 3}

\section{Uji Analisis Data Kecerdasan Emosional}

\begin{tabular}{cccc} 
& & Frekuensi & Persentase \\
\cline { 3 - 4 } Valid & Tinggi & 17 & 19,10 \\
\cline { 3 - 4 } & Sedang & 59 & 66,29 \\
& Rendah & 13 & 14,61 \\
& Total & 89 & 100 \\
\hline
\end{tabular}

Berdasarkan nilai dari mean pada angket kecerdasan emosional adalah 108, 16 dan standar deviasi 7,852. Kemudian dari hasil tersebut dapat diketahui bahwa tingkat kecerdasan emosional dengan kategori tinggi sebanyak 17 orang atau sebesar 19,10 persen, dan kategori sedang sebanyak 59 orang atau sebesar 66,29 persen dan kategori rendah sebanyak 13 orang atau sebesar 14,61persen.

Tabel 4

Uji Hipotesis

Correlations

\begin{tabular}{llrr}
\hline & & $\begin{array}{c}\text { Kebiasaan } \\
\text { Membaca Al- } \\
\text { Qur'an }\end{array}$ & $\begin{array}{c}\text { Kecerdasan } \\
\text { Emosional }\end{array}$ \\
\hline Kebiasaan & Pearson Correlation & 1 &, $460^{* *}$ \\
Membaca Al- & Sig. (2-tailed) & &, 000 \\
Qur'an & $\mathrm{N}$ & 89 & 89 \\
Kecerdasan & Pearson Correlation &, $460^{* *}$ & 1 \\
Emosional & Sig. (2-tailed) &, 000 & 89 \\
\hline
\end{tabular}

**. Correlation is significant at the 0.01 level (2-tailed).

Berdasarkan hasil uji korelasi product moment didapatkan hasil dengan nilai $\mathrm{r}$ hitung sebesar 0,460 dengan $p$ value 0,00 sementara $r$ tabel pada taraf signifikansi 5 persen dengan nilai N 89 adalah 0,213 ( $p$ value < 0,05), maka hipotesis (Ha) diterima dan hipotesis (Ho) ditolak dengan kesimpulan bahwa terdapat pengaruh yang cukup signifikan antara kebiasaan membaca Al-Qur'an terhadap kecerdasan emosional siswa kelas VIII MTs Al-Hamid Banjarmasin. 


\section{Pembahasan}

Penelitian ini bertujuan untuk membuktikan adanya pengaruh kebiasaan membaca AlQur'an terhadap kecerdasan emosional siswa kelas VIII MTs Al-Hamid Banjarmasin. Berdasarkan hasil perhitungan uji korelasi dengan menggunakan teknik korelasi product moment dengan bantuan SPSS 21 didapatkan nilai $r$ hitung sebesar 0,460 dengan $p$ value 0,00 sementara nilai $\mathrm{r}$ tabel pada taraf signifikansi 5 persen dengan $\mathrm{N} 89$ adalah sebesar 0,213. Karena nilai $\mathrm{r}$ hitung yang didapat $(0,460)>\mathrm{r}$ tabel $($ sig 5 persen $=0,213)$ ( $\mathrm{p}$ value $<0,05)$, maka hipotesis $(\mathrm{Ha})$ diterima dan hipotesis (Ho) ditolak, sehingga dapat diambil kesimpulan bahwa terdapat pengaruh yang cukup signifikan antara kebiasaan membaca Al-Qur'an terhadap kecerdasan emosional siswa kelas VIII MTs Al-Hamid Banjarmasin.

Kebiasaan merupakan perilaku yang muncul secara berulang-ulang yang cenderung menetap sehingga akan muncul sebagai perilaku baru dan dilakukan kembali secara otomatis (Syah, 2012). Aspek yang menjadi penyebab munculnya kebiasaan adalah karena adanya stimulus tertentu, stimulus itulah yang nantinya akan menjadi penyebab pengulangan tingkah laku dan berfungsi sebagai penguat dari terbentuknya kebiasaan (Zulhammi, 2015).

Hal ini sesuai dengan teori Bughart mengatakan kebiasaan merupakan salah satu bentuk dari bentuk teori belajar behavioristik yang merupakan aktifitas fisik dan juga mental yang berlangsung terus-menerus sehingga menghasilkan perubahan-perubahan pengetahuan, pemahaman, keterampilan dan nilai sikap (Syah, 2012). Seperti teori menurut B.F Skinner tentang teori Operant Conditioning yang mengatakan proses pembelajaran akan menghasilkan perubahan-perubahan perilaku atas proses pembelajaran yang dilakukan berulang-ulang. Seperti halnya teori pembiasaan klasik yang dikembangkan oleh Ivan Pavlov mengatakan bahwa proses pembelajaran seorang individu ditandai dengan adanya hubungan antara stimulus dan respon, pembiasaan klasik tersebut merupakan akibat dari stimulus. Stimulus itulah yang nantinya menjadi penyebab pengulangan-pengulangan tingkah lakuyang akhirnya akan menjadi kebiasaan dari seorang individu (Zulhammi, 2015). Kebiasaan membaca AlQur'an berarti pengulang-pengulangan berupa aktifitas membaca Al-Qur'an yang dilakukan secara terus menerus sehingga menjadi tingkah laku yang menetap pada seorang individu. 
Kecerdasan emosional merupakan sekumpulan bagian kecerdasan sosial yang kemudian melibatkan kemampuan seseorang dalam memantau perasaan dan emosi diri sendiri maupun orang lain, mampu memilih berbagai informasi sehingga dapat membimbing pikiran maupun tindakannya (Andriani, 2014). Menurut Daniel Goleman kecerdasan emosional dapat di ukur dengan beberapa aspek yaitu, pertama, memiliki kesadaran diri yang baik. kedua, mampu mengelola diri baik dalam mengelola perasaan sehingga mengenal diri dengan baik dan mampu mengembangkan kemampuan diri dan ikut berprestasi, memiliki rasa inisiatif,dan optimis. Ketiga, memiliki rasa sosial seperti rasa empati terhadap sesama, dan kemampuan bersosial yang baik dalam organisasi maupun masyarakat pada umumnya (Goleman, 2007).

Berdasarkan hasil wawancara dengan Wakil Kepala Madrasah Tsanawiyah Al-Hamid Banjarmasin pembiasaan membaca Al-Qur'an di sekolah dibiasakan pada jadwal-jadwal yang teratur yaitu sebelum pembelajaran dimulai, sebelum dzuhur dan 5 menit sebelum pulang sekolah. Sebagaimana yang disampaikan oleh Bapak Ridwan selaku wakil kepala sekolah MTs Al-Hamid.

“Pembiasaan membaca Al-Qur'an ini awalnya hanya saat pagi sebelum pembelajaran, program membaca pagi itu sudah dibiasakan mulai tahun 2003, sudah dari bapak angkatan pertama disini sudah dibiasakan untuk membaca AlQur'an pagi. Selama bapak disini lagi, bapak tingkatkan lagi.kalau pagi khusus 30 tadarus dan tartil itu di jam siang. Jadi siang kami ada tartil lagi sebelum zuhur, menunggu zuhur dan waktu sebelum pulang, 5 menit sebelum pulang."(Ridwan, 2018)

Membaca Al-Qur'an itu sendiri memiliki banyak manfaat terutama dalam aspek psikologis sebagaimana penelitian Erita dari Fakultas Kedokteran dan Ilmu Kesehatan dalam penelitian yang berjudul Pengaruh Membaca Al-Qur'an dengan Metode Tahsin terhadap Depresi di Panti Sosial Tresna Werdha Unit Abiyoso Pakem Yogyakarta mengatakan bahwa membaca Al-Qur'an terbukti dapat mengurangi depresi pada lansia (Erita, 2014). Selain itu dampak membaca Al-Qur'an juga dapat mempengaruhi penurunan tingkat kecemasan sebagaimana penelitian yang dilakukan oleh Rela Mar'ati dan Moh. Tariqur Chaer dalam jurnal penelitian psikologi yang berjudul Pengaruh Pembacaan dan Pemaknaan Ayat-Ayat Al-Qur'an terhadap Penurunan Kecemasan pada Santriwati. Penelitan ini membuktikan bahwa terdapat pengaruh pembacaan dan pemaknaan ayat-ayat Al-Qur'an terhadap penurunan tingkat 
kecemasan pada santriwati yang diberikan perlakuan. Sedangkan santriwati yang tidak diberikan perlakukan cenderung memiliki kecemasan yang turun naik. Hal ini terjadi kerena selain mendapatkan ketenangan dari membaca Al-Qur'an itu sendiri juga dikarenakan proses dari menghafal Al-Qur'an yang membaca Al-Qur'an berulang-ulang namun juga mempengaruhi kognitif dari ayat Al-Qur'an yang dibaca, dihafalkan, dimengerti sehingga memiliki pemahaman yang tepat dalam menilai makna-makna yang terkandung dalam AlQur'an itu sendiri (Mar'ati dan Toriqul Chaer, 2016).

Dari penelitian ini pengaruh kebiasaan Al-Qur'an yaitu perubahan-perubahan tingkah laku yang diterangkan oleh wakil kepala madrasah yang mengatakan bahwa perubahanperubahan terjadi secara bertahap, mulai dari menjadi lebih sopan baik dalam cara ia bergaul dengan sesama teman maupun terhadap guru, berbakti kepada orang tua sejalan dengan visi misi sekolah itu sendiri yaitu mewujudkan terciptanya siswa-siswi yang mempunyai akhlakul karimah, luwes dalam menguasai ilmu agama dan umum, menjadi hafidz Al-Qur'an, agamis, mu'asyarah yaitu pandai bergaul dengan masyarakat, Iman yang dipegang teguh dan dapat mengamalkan ilmu dalam kehidupan dalam sehari-hari (Ridwan, 2018).

Adapun subjek penelitian ini adalah para siswa kelas VIII MTs Al-Hamid Banjarmasin, merupakan sekolah swasta yang berbasis ilmu dan akhlak terpadu, para siswa dididik mengenal mata pelajaran yang sama dengan madrasah pada umumnya yaitu selain mempelajari ilmu umum juga di bekali pelajaran-pelajar agama namun selain itu terdapat mata pelajaran tambahan yaitu tahfidz yang sekaligus menjadi nilai plus di sekolah ini.

Program tahfidz tersebut didukung dengan beberapa waktu tambahan untuk membaca Al-Qur'an yaitu setelah pagi membaca Al-Qur'an bersama disusul dengan setoran hafalan bergantian kepada ustadz-ustadzah yang sudah ada dimasing-masing kelas. Pada waktu bersamaan anak-anak yang lain akan membaca Al-Qur'an secara berulang-ulang secara individu untuk memperlancar hafalan atau menambah hafalan ke-ayat selanjutnya. Selain itu pada setiap hari Senin hingga Kamis sepulang sekolah MTs Al-Hamid juga menyediakan ekstrakulekuler intensif tahfidz bagi siswa-siswi yang berminat lebih pada Al-Qur'an.

Hasil kategori tingkat kebiasaan membaca Al-Qur'an maupun kecerdasan emosional siswa kelas VIII MTs Al-Hamid Banjarmasin masuk dalam kategori sedang. Karena jumlah 
yang berada dalam kategori sedang lebih banyak dari pada yang berada dalam kategori tinggi maupun rendah, yaitu 55 orang (61,79 persen) untuk kebiasaan membaca Al-Qur'an dan 59 orang $(66,29$ persen) untuk kecerdasan emosional dari total subjek 89 orang (100 persen).

Kemudian untuk kecerdasan emosional yang disebar ke 89 subjek, diperoleh data tingkat kecerdasan emosional berada pada kategori sedang karena hasil terbanyak sejumlah 59 orang (66,29 persen), sedangkan yang berada kategori tinggi sebanyak 17 orang (19,10 persen) dan dalam rendah sebanyak 13 orang (14,61 persen) dari hasil data tersebut maka dapat dikatakan bahwa tingkat kecerdasan emosional pada siswa kelas VIII MTs Al-Hamid Banjarmasin masuk kedalam kategori sedang.

Berdasarkan faktor yang mempengaruhi kebiasaan membaca Al-Qur'an salah satunya adalah pada proses pengulangan untuk menjadi kebiasaan itu sendiri. Berdasarkan hasil yang didapatkan ada beberapa siswa yang masih berada kategori rendah pada kebiasaan membaca Al-Qur'an. Berdasarkan hasil wawancara kepada salah satu pengajar, menurut paparan beliau ketika proses pembacaan Al-Qur'an secara individu untuk menghafal masih ada beberapa murid yang enggan untuk membaca, ada beberapa siswa yang bicara pada dan tidak menghafal. Sedangkan siswa yang memiliki tingkat kebiasaan membaca Al-Qur'an tinggi biasa memang tekun saat jam pelajaran tahfidz untuk menghafal dan mengulang bacaan dan beberapa orang juga mengikuti ekstrakulikuler intensif tahfidz. Beberapa faktor yang menyebabkan siswa tidak mau membaca Al-Qur'an pada jam tahfidz dikarenakan memang tidak memiliki minat dalam menghafal Al-Qur'an sedangkan sekolah menjadikan program menghafal menjadi kewajiban seluruh siswa yang ada di MTs Al-Hamid tanpa terkecuali. Program menghafal ini juga telah diketahui para orangtua siswa, sehingga tak jarang hal itulah yang menyebabkan orangtua memasukan anaknya ke MTs Al-Hamid dengan harapan menjadi penghafal Al-Qur'an. Beberapa kasus lain orangtua menyekolahkan anak tanpa meminta persetujuan dari anak tersebut sehingga ia sekolah dengan terpaksa tanpa kemauannya sendiri sehingga hal tersebut membuat ia memiliki minat yang rendah untuk membaca Al-Qur'an dan cenderung memilih diam atau melakukan aktifitas lain pada saat jam tahfidz berlangsung (Ridwan, 2018). Hal itu juga yang menyebabkan masih ada beberapa siswa yang berada dalam kategori rendah pada tingkat kecerdasan emosional. 
Maka dengan hal tersebut dapat disimpulkan bahwa siswa yang memiliki kebiasaan membaca Al-Qur'an dengan kategori rendah ialah mereka dengan tongkat kecerdasan emosional rendah, begitupun sebaliknya siswa dengan kebiasaan membaca Al-Qur'an tinggi maka tingkat kecerdasan emosional merekapun tinggi.

Pengaruh kebiasaan membaca Al-Qur'an terhadap kecerdasan emosional berkaitan tentang pandangan tokoh-tokoh serta ulama yang mengutarakan bahwa membaca Al-Qur'an mengandung banyak manfaat termasuk dalam menangani segi emosinal sejalan dengan penelitian terdahulu yang diteliti oleh Harris Fadhillah, Universitas Negeri Yogyakarta. Sebagaimana yang diterangkan oleh DR. Ahmad al-Qadhi yang juga ingin mengetahui pengaruh Al-Qur'an terhadap kondisi fisiologis seseorang dan mendapatkan bukti bahwa AlQur'an dapat mereduksi ketegangan-ketegangan saraf (fisiologis) (Mar'ati dan Toriqul Chaer, 2016). Sehingga dapat mengurangi tingkat kecemasan dan membuat emosi seseorang lebih stabil.Al-Qur'an yang mendatangkan ketenangan sejalan dengan sabda Rasulullah SAW:

"Tidaklah berkumpul suatu kaum dalam suatu majlis membaca kitab Allah kecuali turun pada mereka ketenangan dan diliputi rahmat dan dikerumuni oleh malaikat dan Allah akan menyebutkan mereka di hadapan para malaikatnya." (HR. Muslim)

Perasaan tenang tadilah yang akan mendatangkan emosi lebih stabil sehingga dapat mengendalikan diri maupun fikirannya. Pengelolaan diri yang baik berasal dari kemampuan seseorang dalam menangani masalah atau perasaan yang membuatnya tertekan. Hal ini terjadi karena selain mendapatkan ketenangan dari manfaat membaca Al-Qur'an seseorang yang membaca Al-Qur'an dengan berulang-ulang juga akan mempengaruhi rekontruksi kognitif dari ayat Al-Qur'an yang dibaca, sehingga memiliki pemahaman yang tepat dalam menilai permasalahan (Mar'ati dan Toriqul Chaer, 2016).

Adapun besarnya pengaruh kebiasaan membaca Al-Qur'an terhadap kecerdasan emosional siswa MTs Al-Hamid Banjarmasin sebesar (rxy2 x 100) atau (21,16 persen) yang berarti ada variabel lain yang mempengaruhi kecerdasan emosinal sebesar 78,84 persen. Adapun faktor-faktor yang mempengaruhi kecerdasan emosinal yaitu faktor otak, keluarga dan lingkungan sekolah. 


\section{Kesimpulan}

Tingkat kebiasaan membaca Al-Qur'an pada siswa MTs Al-Hamid yang berada pada kategori tinggi sebanyak 17 orang (19,10 persen), dalam kategori sedang sebanyak 55 orang (61,79 persen), dan yang berada di kategori rendah sebanyak 17 orang (19,10 persen). Hal ini menujukan bahwa kebiasaan membaca Al-Qur'an di MTs Al-Hamid Banjarmasin tergolong kategori sedang. Tingkat kecerdasan emosional siswa MTs Al-Hamid Banjarmasin berada kategori tinggi sebanyak 17 orang (19,10 persen), dalam kategori sedang berjumlah 59 orang (66,29 persen), dan yang berada di kategori rendah sebanyak 13 orang (14,61 persen). Hal ini menujukan bahwa tingkat kecerdasan emosional di MTs Al-Hamid Banjarmasin tergolong kategori sedang. Berdasarkan hasil uji hipotesis maka didapatkan hasil yang menyatakan bahwa ada pengaruh yang signifikan $(\mathrm{rxy}=0,460 ; \operatorname{sig}=0,00<0,05)$ antara kebiasaan membaca Al-Qur'an terhadap kecerdasan emosional siswa kelas VIII di MTs Al-Hamid Banjarmasin. Hal ini sesuai dengan apa yang diperoleh dari pengeloahan data menggunakan program SPSS 21 dengan $r$ tabel $=0,254$ dan rxy ( $\mathrm{r}$ hitung) 0,460. Dikatakan signifikan apabila rxy lebih besar dari $r$ tabel, hal ini sesuai dengan yang peneliti dapatkan, nilai $r x y=0,460>r$ tabel $=0,254$ sehingga hasil yang ditemukan adalah signifikan. Besarnya pengaruh kebiasaan membaca Al-Qur'an terhadap kecerdasan emosinal sebesar 28,4 persen, artinya terdapat pengaruh kebiasaan membaca Al-Qur'an terhadap kecerdasan emosinal.

Saran

Bagi lembaga terkait yaitu MTs Al-Hamid Banjarmasin agar terus meningkatkan motivasi untuk terus membaca Al-Qur'an dengan senantiasa memberikan materi-materi tentang manfaat dan fadilah yang diperoleh bagi pembaca Al-Qur'an. Serta memberikan penanganan khusus kepada siswa yang masih berada pada kategori rendah dalam kebiasaan membaca Al-Qur'an. Bisa berupa pembelajaran Al-Qur'an secara individu dengan waktu tambahan ataupun pemberian penanganan khusus secara individu terkait menambah minat untuk terus meningkatkan kebiasaan membaca Al-Qur'an. Bagi subjek penelitian, diharapkan untuk meningkatkan kesadaran diri dan lebih bersemangat lagi untuk membaca dan mempelajari AlQur'an. Kemudian untuk peneliti selanjutnya, diharapkan dapat meneliti lebih mendalam dan melakukan wawancara pasca penelitian untuk mampu memperkuat hasil yang didapat. 


\section{Referensi}

Andriani, A. (2014). Kecerdasan Emosional (Emotional Quotient) dalam Peningkatan Prestasi Belajar. EDUKASI: Jurnal Pendidikan Islam, 2(1), 459â - 472.

Goleman, D. (2016). Kecerdasan Emosional.Terj. T. Hermaya. Jakarta: PT. Gramedia Pustaka Utama.

Goleman, D., \& dkk. (2007). Kepemimpinan Berdasarkan kecerdasan Emosi, terj. Susi Purwoko. Jakarta: PT. Gramedia Pustaka.

Jati, G. W., \& Yoenanto, N. H. (2013). Kecerdasan Emosional Siswa Sekolah Menengah Pertama Ditinjau dari Faktor Demografi. Jurnal Psikologi Pendidikan dan Perkembangan, 2(2), 109_ 123.

Mar'ati, R., \& Chaer, M. T. (2017). Pengaruh Pembacaan dan Pemaknaan Ayat-ayat al-Qur'an terhadap Penurunan Kecemasan pada Santriwati. Psikohumaniora: Jurnal Penelitian Psikologi, 1(1), 30-48.

Mar'ati, R., \& Toriqul Chaer, M. (2016). Pengaruh Pembacaan dan Pemaknaan Ayat-ayat Al-Qur'an terhadap Penurunan Kecemasan pada Santriwati. Vol. 1 No. 1, 6.

Mustolehudin. (2011). Tradisi Baca Tulis Dalam Islam Kajian Terhadap Teksi Al-Qur'an Surah Al'Alaq Ayat 1-5. Analisa, 18(01), 145.

Ridwan, M. (2018). Wawancara Pribadi.

Sarwono, S. (2012). Psikologi Perkembangan. Jakarta: Rajawali Press.

Susanti, I. (2015). Perilaku Menyimpang Dikalangan Remaja Pada Masyarakat Karangmojo Plandaan Jombang. Paradigma, 3(2).

Syah, M. (2012). Psikologi Belajar. Jakarta: Raja Wali Press.

Titisari, H. T. D. (2018). Hubungan antara Penyesuaian diri dan Kontrol diri dengan Perilaku Delikuen pada siswa SMA Muhammadiyah 1 Jombang. PSIKODIMENSIA, 16(2), 131141.

Zulhammi, Z. (2015). Teori belajar behavioristik dan humanistik dalam perspektif pendidikan Islam. DARUL'ILMI: Jurnal Ilmu Kependidikan dan Keislaman, 3(1), 105-125. 